\title{
Human Rights and International Economic Law
}

\author{
Sarah Joseph*
}

\section{Introduction}

International human rights law emerged around the same time as modern international economic law, out of the ruins of the Second World War. ${ }^{1}$ The Breton Woods conference focused on building the architecture of global economic cooperation and security, while the newly formed United Nations ("UN") recognised that human rights were a matter of legitimate international focus and regulation in the wake of the shocking crimes of World War II. The original General Agreement on Tariffs and Trade ("GATT") was adopted in 1947, while the Universal Declaration of Human Rights (“UDHR”) was adopted in 1948.

Most globally recognised human rights are listed in the International Bill of Rights, comprising the UDHR and the two treaties which enshrine its norms, the International Covenant on Civil and Political Rights 1966 ("ICCPR") and the International Covenant on Economic Social and Cultural Rights 1966 ("ICESCR"). These rights are complemented by seven other core UN human rights treaties, which focus on particular types of human rights victims (eg children, migrant workers, people with disabilities) or particular types of human rights abuses (eg discrimination on the basis of race or sex, torture, disappearances). Human rights are also protected under regional treaties, as well as customary international law.

For ease of analysis, the International Bill of Rights, particularly the two Covenants, will be the focus of "human rights" for the purposes of this paper. Below I address the extent to which international economic law is compatible with those human rights. The commentary will largely focus on international trade law, as represented by WTO law, with the final part of the paper focusing on potential conflicts between human rights law and international investment law.

\section{International Human Rights Law - some Basics}

The ICCPR protects civil and political rights. ${ }^{2}$ It has 168 States parties as at March 2015. Civil and political rights can be categorised as encompassing rights of (1) physical and spiritual integrity and autonomy; (2) rights of fair treatment; and (3) rights to participate

\footnotetext{
* Thanks to Adam Fletcher for assisting in preparing the footnotes and format of this paper.

${ }^{1}$ Much of the following commentary is adapted from Joseph, Blame it on the WTO: A Human Rights Critique, 2011 and Joseph, Trade Law and Investment Law, in: Dinah Shelton (ed.), The Oxford Handbook of International Human Rights Law, 2013, pp. 841-870.

2 The following commentary is adapted from Joseph, Civil and Political Rights, in: Baderin/Ssenyonjo, International Human Rights Law: Six Decades after the UDHR, 2010, p. 89 (90).
} 
meaningfully in the political process. ${ }^{3}$ Category 1 includes the rights to life and freedom from torture and other ill treatment, freedom of movement and the right to privacy. Spiritual autonomy is ensured by rights such as the freedoms of expression, religion, belief and thought. Category 2 encompasses fairness in a narrow procedural sense, such as the right to a fair trial, and in a broader sense, such as a general right of equal protection of the law and freedom from non-discrimination. Category 3 obviously encompasses the right to vote and to stand for election, and also includes rights which are essential for a healthy political process, such as the freedoms of assembly and association. The three categories overlap considerably. The ICCPR has a strong obligation provision in Article 2(1), whereby States parties are required to immediately guarantee all of the rights therein to all within jurisdiction.

The ICESCR protects economic social and cultural ("ESC") rights, and has 164 States parties as at March 2015. Economic rights are rights related to labour and employment, contained in Articles 6 to 8 of the ICESCR, ${ }^{4}$ as well as the accrued benefits of labourers and social safety nets for those who cannot work in Article 9 (the right to social security). Social rights are those needed to function adequately in society such as the right to family life (Article 10), the right to an adequate standard of living (Article 11), the right to health (Article 12) and the right to education (Articles 13 and 14). Article 15 covers cultural rights, including the right to participate in the cultural life of society and to benefit from scientific progress. The distinction between the three categories is not watertight, and indeed is often ignored. ${ }^{5}$ The ICESCR has a weaker obligation provision than the ICCPR: its Article 2(1) requires the progressive implementation of the rights therein, and is qualified by the resources available to a State.

States have duties to respect, protect, and fulfil all human rights. The duty to respect is a duty to refrain from activities that harm human rights. The duty to protect is the duty to take reasonable measures to protect people from harm to their human rights by other entities, such as individuals or corporations. States are required to regulate private entities in order to ensure, as far as is reasonably possible, that they do not harm the human rights of others. For example, the regulation of health and safety standards helps to ensure that workers' rights are not infringed by their employers. The duty to fulfil includes the duty to take the measures necessary to ensure that individuals enjoy their human rights. Examples of implementation of this obligation would be the provision of subsidies to ensure access by the poor to essential goods and services such as water, health care and education.

It has been argued in a number of philosophical and political circles that ESC rights are not "real" human rights, ${ }^{6}$ or that they lack sufficient content to be useful in an international

\footnotetext{
3 See also Davidson, Introduction, in: Conte/Davidson/Burchill, Defining Civil and Political Rights: The Jurisprudence of the United Nations Human Rights Committee, 2004, p. 2.

${ }^{4}$ Articles 6-8 cover, respectively, the rights to work, to just and favourable conditions of work, and to join trade unions.

5 Alston/Goodman, International Human Rights, 2013, p. 286.

${ }^{6}$ Harrison, The Human Rights Impact of the World Trade Organisation, 2007, p. 26 (noting but not agreeing with the argument). See, eg, Human Rights Survey, The Economist (5 December 1998), p.9, suggesting that economic social and cultural rights are issues that "should be left to politics and the market".
} 
economic context. ${ }^{7}$ Such an argument ignores the fact that three quarters of the world's nations have committed to international legal obligations under the ICESCR, and that that such rights are enforceable in numerous domestic courts. ${ }^{8}$ The adoption of an Optional Protocol to the ICESCR in 2008, which allows for individual complaints of ICESCR violations at the international level, puts to bed the contention that such rights are nonjusticiable. ${ }^{9}$ Such arguments are essentially ideological, or reflect a lack of understanding of international human rights law. ${ }^{10}$

The Achilles heel of the international human rights system lies in its enforcement, or lack thereof. No global body, apart from the UN Security Council and the International Court of Justice, is empowered to make legally binding decisions on human rights. ${ }^{11}$ The Security Council and ICJ rarely deal with human rights matters, though the number of human rights cases before the ICJ has increased in recent years. Enforcement against recalcitrant States takes place largely by the process of naming and shaming. While shame can prompt behavioural change by a State, it is clearly a weak enforcement measure compared to the economic consequences that ensue from non-compliance with the rulings of dispute resolution bodies in the WTO, ${ }^{12}$ or from ignoring the decision of an investment tribunal. The record of compliance with the rulings of UN human rights bodies pales in comparison to the record of compliance by WTO members with the WTO dispute settlement bodies.

The discrepancy in the strength of the enforcement regimes means that a de facto hierarchy can develop, with trade and investment rules prevailing over human rights rules, due to the stronger enforcement system under the WTO and BITs compared to the global human rights system. ${ }^{13}$ The disproportionate strength of the trade and investment regimes compared to the human rights regime can lead to prioritisation of the former norms if they conflict with human rights norms, or regulatory chill as States may fail to adopt measures to protect human rights because they fear that such measures might breach trade and investment law. ${ }^{14}$

\footnotetext{
7 See, eg, Marceau, WTO Dispute Settlement and Human Rights European Journal of International Law 13 (2002), pp. 753 (786-789); Alvarez, How not to Link: Institutional Conundrums on an Expanded Trade Regime, Widener Law Symposium Journal 7 (2001) 1, p. 10.

${ }^{8}$ See Langford, The Justiciability of Social Rights: From Practice to Theory, in: Langford (ed.), Social Economic Rights Jurisprudence: Emerging Trends in International and Comparative Law, 2008, pp.3, 4.

9 The Optional Protocol came into force on 5 May 2013, after its tenth ratification. At the time of writing, it had 19 States parties.

${ }^{10}$ Howse/Teitel, Beyond the Divide: The Covenant on Economic, Social and Cultural Rights and the World Trade Organization, in Joseph/Kinley/Waincymer, The World Trade Organization and Human Rights: Interdisciplinary Perspectives, 2009, p. 40.

${ }^{11}$ Regional human rights courts are stronger, as they are empowered to make legally binding decisions.

12 See Alston, Resisting the Merger and Acquisition of Human Rights by Trade Law: A Reply to Petersmann, European Journal of International Law 13 (2012), p. 815 (833); Vázquez, Trade Sanctions and Human Rights Past, Present and Future, Journal of International Economic Law 6 (2003), p. 797 (803-804).

13 Salomon, Global Responsibility for Human Rights, 2007, p. 155.

14 The issue of the actual hierarchy in law between the two sets of norms is beyond the scope of this paper. See Joseph, Blame it on the WTO: A Human Rights Critique, 2011, pp. 46-50.
} 


\section{International Trade Law and ESC Rights}

\section{Congruence}

Freer trade across borders is said to increase nett wealth in the world. The economic advantages of liberalised trade regimes are supported by David Ricardo's nineteenth century theory of comparative advantage. Ultimately, the theory holds that global free trade will generate greater global wealth, a goal that is congruent with human rights law, given that it should increase the capacity of States to protect ESC rights.

Free trade can facilitate people's access to important products and services which facilitate their enjoyment of ESC rights. For example, in 2002 Oxfam International noted that some African countries imposed a very high tariff on mosquito nets, surely a measure that cost lives by increasing the exposure of the poor to malaria, in probable breach of the right to health. ${ }^{15}$

There is little doubt that trade obstacles can harm overall welfare and also specific human rights. For example, the World Bank reported that US and European cotton subsidies depressed world cotton prices by $71 \%$ in 2001-2 with devastating effects for the incomes of cotton growers in Africa and central Asia, ${ }^{16}$ and therefore their rights to work and to a livelihood. ${ }^{17}$ The potential generation of human rights harms by protectionist measures indicates that, in principle, some limitation on the regulatory power of the State to restrict free trade is welcome from a human rights point of view. ${ }^{18}$

\section{Bias against the Poor}

WTO rules favour the interests of developed States over poorer developing States, a systemic bias conceded by the immediate past WTO Director General Pascal Lamy in 2006. ${ }^{19}$ Cambridge University economist Ha-Joon Chang agrees, stating that WTO trading rules "favour free trade in areas where the rich countries are stronger but not where they are weak". ${ }^{20}$

\footnotetext{
15 Oxfam International, Rigged Rules and Double Standards, 2002, p. 62.

16 World Bank, World Development Report 2006, 2006, p. 212.

17 See, eg, WTO, Poverty reduction: sectoral initiative in favour of cotton, WTO Committee on Agriculture, WTO doc. TN/AG/Gen.4 (16 May 2003). For an update, see Lazzeri, Western Cotton Subsidies Endanger African Farmers, Africa Europe Faith and Justice Network, available at: http://www.aefjn.org/index.php/352/articles/western-cotton-subsidies-endanger-african-farmers.html (accessed 16 March 2015).
}

\footnotetext{
There are strong arguments that a State, such as the US, owes human rights obligations to people in other countries, such as cotton growers in Africa, in certain circumstances. See Maastricht Principles on Extraterritorial Obligations in the area of Economic, Social and Cultural Rights, a set of principles adopted by international experts in 2010, available at: http://www.etoconsortium.org/nc/en/library/maastrichtprinciples/?tx drblob pi1\%5BdownloadUid\%5D=23 (accessed 26 March 2015).

18 Joseph, Blame it on the WTO: A Human Rights Critique, 2011, p. 119.

19 Lamy, It's Time for a new "Geneva Consensus" on making trade work for development, Emile Noel Lecture New York University Law School, New York (30 October 2006), available at: https://www.wto.org/english/news_e/sppl_e/sppl45_e.htm (accessed 15 March 2015).

${ }^{20}$ Chang, Bad Samaritans: The Myth of Free Trade and the Secret History of Capitalism, 2008, p. 13.
} 
Such a state of affairs is hardly surprising if one considers the economic and political power equations in existence at the time the WTO treaties were negotiated and concluded in the 1980s and early 1990s. Imbalances of power have continued during negotiations for further liberalisation in the Doha round. Certainly, emerging economies such as China, India and Brazil, have asserted themselves in current negotiations, which is one reason why they have stalled. Meanwhile, the current biased rules prevail.

With current rules tilted against poorer States, the WTO is not achieving optimal outcomes in alleviating poverty, and therefore in promoting the capacity of States to fulfil ESC rights. At worst, unbalanced WTO rules hamper development and exacerbate poverty in the poorest states, thereby prejudicing the realization of ESC rights. In this respect, the economists Joseph Stiglitz and Andrew Charlton reported in 2005 that, by some estimates, 48 of the least developed countries had suffered economic losses of close to US\$600 million per year since they began implementing WTO agreements. ${ }^{21}$

The bias in WTO rules against developing nations is demonstrated by the WTO's Agreement on Agriculture ("AoA"). Many developing States have a comparative advantage in agricultural products, but the AoA allows significant protectionism to their detriment. For example, the AoA does not combat 'tariff escalation", that is the escalation of tariffs imposed on processed agricultural goods compared to raw goods. Such tariff schemes, commonly imposed by developed States, stunt the growth of more sophisticated and lucrative agricultural industries in source countries. ${ }^{22}$ Other egregious examples of agricultural protectionism include Europe's sugar markets ${ }^{23}$ and US cotton markets (as mentioned above). It is unsurprising that some of the most prominent demands of developing states in the current round of WTO negotiations are for further agricultural liberalisation.

\section{Does free trade alleviate poverty?}

A more fundamental issue is whether trade liberalisation generally assists States in alleviating poverty and promoting and protecting ESC rights. ${ }^{24}$ Over time, the strategy may well be beneficial, but swift liberalisation as pushed in bilateral and regional treaties, and in the Doha round, may not be favourable for ESC rights. For example, the loss of tariff revenue creates a significant hole in the budgets of developing States which is difficult to replace, because tariffs are relatively simple to administer compared to internal taxes. ${ }^{25}$

Premature trade liberalisation may trap a developing State in primary production and low cost unskilled manufacturing, where it has a current comparative advantage, but which is disadvantageous in the long term. Ha-Joon Chang argues that liberalisation is "absolutely right" for States that are willing to accept their "current levels of technology as given", but it

\footnotetext{
21 Stiglitz/Charlton, Fair Trade for All, 2005, p. 47.

22 See Oxfam International, Rigged Rules and Double Standards, 2002, pp. 102-103.

23 Vandenhole, Third state obligations under the ICESR: a case study of EU sugar policy, Nordic Journal of International Law 76 (2007), p. 73.

24 Joseph, Blame it on the WTO: A Human Rights Critique, 2011, pp. 164-169.

25 The International Monetary Fund has estimated that, between 1980 and 2005, less than 30\% of lost tariff revenue was recovered by developing States through other means: Baunsgaard/Keen, Trade Revenue and (or?) Trade Liberalisation, IMF Working Paper No. 05/112 (2005).
} 
is not appropriate where States wish to "acquire more advanced technologies" and develop their economies. ${ }^{26}$ A gradual sequenced approach to liberalisation in developing States, incorporating the development of appropriate institutional capacities and dynamic niche industries, is preferable to the reduced policy space entailed in rapid and potentially premature liberalisation. ${ }^{27}$ Therefore, it is possible that liberalised trade can hinder the capacity of States to abide by their obligations to progressively guarantee ESC rights.

\section{The rights of the losers from free trade}

Fundamentally, WTO rules compel States to liberalize their trade regimes. Trade liberalization undoubtedly creates winners and losers, with the latter being those in uncompetitive industries. Those losers do not inevitably find new jobs, especially in the developing world where there is already an oversupply of labour, ${ }^{28}$ and therefore suffer detrimental social consequences and loss of enjoyment of ESC rights. WTO rules do not demand that States take measures to compensate the losers, nor do they require States to ensure that the gains from free trade are equitably distributed. Those matters are left to the discretion of Member States. Therefore, the WTO mandates that States adopt policies that harm certain people, yet it does nothing to ensure recompense for those harmed. In contrast, the treatment of losers from trade liberalization is crucial from a human rights point of view. This does not mean that there can be no losers. Rather, it means that appropriate measures must be taken to alleviate the detrimental human impact of free trade reforms. Unfortunately, developing States often lack the capacity to do so.

Why are obligations regarding the dismantling of free trade obstacles felt to be worthy of explicit internationalisation within the free trade agenda, while measures regarding redistribution and other social welfare issues associated with trade, such as labour protections and fair distribution of the gains of trade, are omitted? As noted by Andrew Lang, "what we currently think of as "trade issues" and "trade values" are not predetermined but are in part a matter of choice'. ${ }^{29}$ The exclusion of the 'welfare' side of the 'embedded liberal' free trade bargain from the $\mathrm{WTO}^{30}$ is a political choice, rather than an incontestable given.

The problem is exacerbated by the adoption of prevailing WTO rules in an era where neoliberal economic theories have predominated. Neo-liberalism has also influenced the contemporaneous policies of other key international economic bodies such as the International Monetary Fund and the World Bank, ${ }^{31}$ and the philosophy underlies

26 Chang, Bad Samaritans: the Myth of Free Trade and the Secret History of Capitalism, 2008, p. 47.

27 See Rodrik, How to Save Globalisation from its Cheerleaders, The Journal of International Trade and Diplomacy 1 (2007), p. 1, available at: http://dev.wcfia.harvard.edu/sites/default/files/Rodrick_HowToSave.pdf (accessed 15 March 2015).

${ }^{28}$ Stiglitz/Charlton, Fair Trade for All, 2005, pp. 6, 26 and 194.

${ }^{29}$ Lang, Reflecting on 'Linkage': Cognitive and Institutional Change in the International Trading System, Modern Law Review (2007) p. 523 (545).

${ }^{30}$ Ruggie, International Regimes, Transactions and Change: Embedded Liberalism in the Postwar Economic Order International Organization 36 (1982) p. 379 (393-398), famously suggested the pre-WTO GATT regime was based on a premise of 'embedded liberalism', whereby GATT members agreed to reduce protectionist measures, whilst simultaneously promulgating domestic welfare policies to provide safety nets for the losers from liberalised trade.

31 See, eg, Gathii, Re-Characterizing the Social in the Constitutionalization of the WTO: A Preliminary Analysis, Widener Law Symposium Journal 7 (2001), p. 137 (152-153); Stiglitz, Freefall: Free Markets and the Sinking of the Global Economy, 2010, p. 220. 
international investment law. Neoliberalism upholds the invisible hand of the market as the appropriate guiding force for economies with minimal state intervention. Given that redistribution and compensation for "the losers from trade" normally requires State intervention, neoliberalism does not ideologically support such measures.

Neoliberal thinking dictates that the market should be cordoned off from politics and be left to its own devices. "[D]emocracy is acceptable to neo-liberals only in so far as it does not contradict the free market". ${ }^{32}$ However, such a demarcation of economics and politics is a political position: state abstention has consequences just like state intervention. ${ }^{33}$ If the market is left unregulated by public power, market forces may be distorted by imbalances of private power. The "market" does not form a neutral baseline. Rather, non-intervention "assumes that the existing distribution of wealth and entitlements is legitimate". ${ }^{4}$ As colourfully stated by Frank Garcia, the "efficiency model" promoted by the WTO and most economists needs to be "flushed ... out of its assumed neutrality and into the mud pit of normative brawling, where it belongs". ${ }^{35}$

\section{Case study: the right to food}

The right to food is recognised in Article 11 of the ICESCR. Article 11(1) generally guarantees the right to an adequate standard of living for a person and his/her family, including "adequate food". In General Comment 12, the Committee on Economic Social and Cultural Rights confirmed that the right to food entails, for all, "physical and economic access at all times to adequate food or means for its procurement". ${ }^{36}$

Real concerns exist about the impact of liberalised trade on the enjoyment of the right to food. Trade literature emphasises that free markets will divert to those who sell for less, but markets also divert to those willing to pay more. ${ }^{37}$ For example, more of the finite amounts of arable land are being used to cultivate and feed livestock for meat to satisfy the more expensive tastes of a growing middle class in Asia instead of growing staple foods for the poor and the hungry. ${ }^{38}$ Similarly, biofuel production has diverted many crops which traditionally feed the poor ${ }^{39}$ into products which are used by the rich to drive their cars. ${ }^{40}$

\footnotetext{
${ }^{32}$ Ha-Joon Chang, Bad Samaritans: The Myth of Free Trade and the Secret History of Capitalism, 2008, p. 176.

33 Gathii, Re-Characterizing the Social in the Constitutionalization of the WTO: A Preliminary Analysis, Widener Law Symposium Journal 7 (2001), p. 137 (168-169).

${ }^{34}$ Gathii, Re-Characterizing the Social in the Constitutionalization of the WTO: A Preliminary Analysis, Widener Law Symposium Journal 7 (2001), p. 137, (167-168).

35 Garcia, Trade, Inequality, and Justice: Toward a Liberal Theory of Just Trade, 2003, p. 17.

36 Committee on Economic, Social and Cultural Rights, General Comment 12: The right to adequate food (Art. 11), UN doc. E/C.12/1999/5 (12 May 1999), para 6.

37 De Schutter, International Trade in Agriculture and the Right to Food, Dialogue on Globalization Occasional Paper No. 46, 2009, pp. 10-11.

38 Murphy, Concentrated Market Power and Agricultural Trade, Ecofair Trade Dialogue Discussion Paper No. 1 (English Version), August 2006, , p. 27.

39 Human Rights Council, Report of the Special Rapporteur on the right to food, Olivier De Schutter: Building resilience: a human rights framework for world food and nutrition security, UN doc. A/HRC/9/23 (8 September 2008), para 28.

${ }^{40}$ Commission on Human Rights, Report of the Special Rapporteur on the right to food, Jean Ziegler, UN doc. E/CN.4/2005/47 (24 January 2005), para 23; Annex 2, para 10.
} 
International agricultural markets suffer from a number of flaws that can exacerbate hunger and prejudice enjoyment of the right to food, given that $50 \%$ of the world's hungry are in fact small agricultural producers. ${ }^{41}$ Agricultural commodities markets have generally delivered poor and erratic returns to producers over the last three decades. ${ }^{42}$ A number of factors cause these markets to defy the orthodox economic theories regarding supply and demand. ${ }^{43}$ It is difficult to tailor supply to demand due to the vagaries of climatic conditions, and the fact that land cannot be easily moved 'in and out of production' 44 to suit market conditions. Low prices mean that many farmers cannot make a decent living. Price hikes are too unpredictable for those farmers to take advantage of, and they also suffer as consumers with sudden rises in food prices.

Global agricultural trade is dominated by large-scale single-crop farms owned by multinational agribusiness companies. ${ }^{45}$ Indeed, many commodities markets are dominated by only a few agribusiness multinationals. ${ }^{46}$ To some extent, the growth of global supply chains benefits smaller farmers by connecting them to global markets. ${ }^{47}$ However, cartelisation within these supply chains has created severe power imbalances between producers and buyers, allowing the latter to exercise effective monopsony power to drive down prices paid to producers. ${ }^{48}$ Yet measures to combat private monopolies are 'conspicuously absent' from the WTO. ${ }^{49}$

The dominant agribusiness corporations are 'more likely to be concerned with profitable trade than with local-level food security'. ${ }^{50}$ Export orientation in agriculture has prompted switches from subsistence products to non-food cash crops, such as coffee, cocoa and tobacco. ${ }^{51}$ The diversion of resources from food can weaken local food security and transform a country into a net food importing country, with all of the vulnerabilities associated with that status.

${ }^{41}$ UN Millennium Project, Halving Hunger: It can be done, summary of the report of the task force on hunger, The Earth Institute, Columbia University, 2005, pp. 4-6, available at: http://www.unmillenniumproject.org/documents/HTF-SumVers_FINAL.pdf (accessed 16 March 2015).

${ }_{42}$ UNGA, Report of the Special Rapporteur on the Right to Food, Olivier De Schutter, UN doc. A/63/278 (21 October 2008), para 18.

${ }^{43}$ Human Rights Council, Report of the Special Rapporteur on the right to food, Olivier De Schutter: Mission to the World Trade Organization, UN doc. A/HRC/10/5/Add.2 (25 June 2008), para 21; Wolf, Why Globalisation Works, 2005, p. 206.

${ }^{44}$ Murphy, WTO Agreement on Agriculture: Suitable Model for a Global Food System?, Foreign Policy in Focus 7 (2002), p. 3.

${ }^{45}$ Breining-Kaufman, The Right to Food and Trade in Agriculture, in: Cottier/Pauwelyn/Bürgi (eds.), Human Rights and International Trade, 2005, p. 368.

46 World Bank, World Development Report 2008: Agriculture for Development, 2008, pp. 135-136.

47 De Schutter, International Trade in Agriculture and the Right to Food, Dialogue on Globalization Occasional Paper No. 46, 2009, p. 30.

48 United Nations Development Programme [UNDP], Human Development Report 2005: International Cooperation at a Crossroads: Aid, Trade and Security in an Unequal World, 2005, pp. 142-143.

${ }^{49}$ United Nations Development Programme [UNDP], Human Development Report 2005: International Cooperation at a Crossroads: Aid, Trade and Security in an Unequal World, 2005, p. 139.

${ }^{50}$ Dommen, Raising Human Rights Concerns in the World Trade Organization: Actors, Processes and Possible Strategies, Human Rights Quarterly 24 (2002), p. 1 (34).

${ }^{51}$ United Nations Human Settlements Programme, Global Report on Human Settlements 2006: The Challenge of Slums, 2006, p. 41. 
The above problems conspire to leave vast numbers of small farmers extremely vulnerable in the world economy. Economists might advise many of them to move into more efficient industry sectors. But modern mechanised agribusiness cannot employ them all and their skills are not easily adaptable to non agricultural or urban industries. Furthermore, the ability of the many poor rural women to simply "move" to new areas and jobs is seriously hindered by cultural barriers. Further, extensive reduction in smallholders will only exacerbate some of the problems regarding the lack of competition in markets and overemphasis on cash crops. Finally, the assertion that smallholders should give up their land and independence arguably treats them as economic units rather than as human beings with human rights.

Agricultural activities are commercial activities, but they are also truly multifunctional, serving purposes beyond the production of commodities. They promote human welfare, traditional cultural practices, and the provision of environmental and ecological services. ${ }^{52}$ While the AoA acknowledges 'non-trade' concerns in some of its provisions, such as food security and environmental protection, overall it "clearly fits into a programme of trade liberalization in agricultural products". ${ }^{53}$ In contrast, many experts, including from economic fields, argue that new agricultural management systems must be devised so as to serve these multifunctional purposes. ${ }^{54}$

\section{Trade Law and Civil and Political Rights}

Free trade and investment can facilitate the introduction of products and services that boost civil and political rights. For example, the use of social media, involving access to the internet and social media sites (services), mobile phones, and computers (products) in the Arab Spring facilitated the overthrow of long-standing dictatorships in Tunisia and Egypt in early 2011. ${ }^{55}$ Having said that, the souring of that revolution in Egypt gives us pause to wonder whether it was premature, with technology perhaps driving the revolution forward before its proponents were properly organised for the aftermath. ${ }^{56}$ These days social media is proving to be an effective recruitment tool for the barbaric Islamic State group. Technology is of course neither "good" nor "bad" - it depends on the context in which it is used. After all,

\footnotetext{
52 International Assessment of Agricultural Knowledge [IAAKSTD], Science and Technology for Development, Agriculture at the Crossroads, 2009, Executive Summary, p. 6; World Bank, World Development Report 2008: Agriculture for Development, 2008, p. 2.

53 Human Rights Council, Report of the Special Rapporteur on the right to food, Olivier De Schutter: Mission to the World Trade Organization, UN doc. A/HRC/10/5/Add.2 (25 June 2008), para 14.

${ }^{54}$ International Assessment of Agricultural Knowledge, Science and Technology for Development [IAAKSTD], Agriculture at the Crossroads, 2009, p. 50.

${ }^{55}$ See Dubai School of Government, Civil Movements: The Impact of Facebook and Twitter Arab Social Media Report 1 (2011) 2; Howard and others, Opening Closed Regimes: What Was the Role of Social Media during the Arab Spring?, Working Paper 2011.1, 2011, available at: http://pitpi.org/wpcontent/uploads/2013/02/2011_Howard-Duffy-Freelon-Hussain-Mari-Mazaid_pITPI.pdf (accessed 7 March 2015).

${ }^{56}$ Morozov, The Net Delusion, 2011, p. 196.
} 
surveillance technology, to assist in the identification and suppression of dissidents, can also be traded across borders. ${ }^{57}$

Could trade rules directly assist in the protection and fulfilment of civil and political rights? In this regard it is intriguing to speculate on whether China's infamous internet censorship rules breach its WTO obligations. China censors internet access via the "Great Firewall”, which blocks or slows foreign internet sites. The level of censorship imposed by China breaches the human right to freedom of expression. ${ }^{58}$ The firewall apparently "degrades the performance of websites based outside the country", ${ }^{59}$ so an argument may be made that it impairs foreign competition via the internet in China's huge market. Indeed, Google rapidly lost market share in China after moving its operations outside the firewall, temporarily, early in $2010 .^{60}$

WTO law could therefore prove to be an ally of those who seek greater internet freedom in China. We will not find out unless a State instigates a relevant complaint. The key issue, however, in any resultant dispute would not be human rights, but the scope of China's WTO obligations and the extent of impairment to foreign trade. ${ }^{61}$

More generally, Pascal Lamy has stated that global trade rules are "a rampart against totalitarianism". ${ }^{62}$ Indeed, it is commonly argued that economic openness promotes political openness in the following ways. Economic openness promotes economic growth, which helps to create new economic elites, who can challenge the authority of dictatorial government power, creating further space for civil society. It leads to the creation of a middle class, which is more educated and which eventually demands greater political and social freedom. ${ }^{63}$

These theories are backed up by evidence: democracy and civil and political freedoms tend to flourish more in richer developed States, which generally have more liberal trade and

\footnotetext{
${ }^{57}$ Joseph, Social Media, Political Change, and Human Rights, Boston College International and Comparative Law Review 35 (2012), p. 145 (168).

${ }^{58}$ Freedom of expression is recognised in Article 19 of the UDHR and Article 19 of the ICCPR. While China is not a party to any treaty that guarantees freedom of expression, it is arguable that the right is protected under customary international law. In any case, greater enjoyment of freedom of expression in China would boost the enjoyment of civil and political freedom in that country, regardless of China's human rights obligations.

59 Scheer, Obama should back Google with more than rhetoric: the US should challenge China's "firewall" before the WTO, The Huffington Post, 25 May 2011, available at: http://www.huffingtonpost.com/peterscheer/obama-should-back-up-goog_b 425724.html (accessed 15 March 2015).

60 See, eg, Google losing market share in China, The Boston Globe, 23 April 2010.

61 See, generally, Wu, The World Trade Law of Censorship and Internet Filtering (3 May 2006), p. 10, available at: http://papers.ssrn.com/sol3/papers.cfm?abstract_id=882459 (accessed 15 March 2015).

62 Lamy, Towards Shared Responsibility and Greater Coherence: Human Rights, Trade and Macroeconomic Policy, Speech at the Colloquium on Human Rights in the Global Economy, Co-organized by the International Council on Human Rights and Realizing Rights, Geneva, 13 January 2010, available at: http://www.wto.org/english/news_e/sppl_e/sppl146_e.htm (accessed 15 March 2015).

63 See Garcia, The Global Market and Human Rights: Trading away the Human Rights Principle, Brooklyn Journal of International Law 7 (1999), p. 51 (59); Bhagwati, Free Trade Today, 2002, pp. 43-44.
} 
investment regimes, than in poorer developing countries, which generally have more restrictive regimes. ${ }^{64}$

However, the above arguments are contestable. Singapore has long had an open economy, yet has only slowly increased its observance of civil and political freedoms. Similarly, economic reforms in China have not been matched by significant improvements in civil and political rights. ${ }^{65}$ And, as noted above, some developing States have experienced poor economic performance rather than growth in eliminating trade barriers.

Furthermore, the spread of marketization across the world has accompanied greater global inequality. ${ }^{66}$ Trade and investment policies do not mandate any form of domestic wealth distribution. The benefits of economic growth might flow only to a small elite. When gaps between elites and the poor grow, there is a more pronounced divergence in their interests, leading to the possible generation of rules and institutions which favour the latter over the former. ${ }^{67}$ Greater inequality may therefore lead to greater marginalisation and intolerance of the poor.

Harvard Professor Amy Chua has questioned the assumption that the twin trajectories of free trade and democracy in the developed world will recur in the developing world. First, she notes that the development of democracy and free trade regimes in industrialised States was slow; universal suffrage and economic liberalisation evolved over centuries.

In contrast, comparable economic transitions in developing States have been remarkably swift, and have not allowed time for the development of economic safety nets, or the development of aspirational pro-market ideologies amongst a population. ${ }^{68}$ In such circumstances, the impoverished majority may be very hostile to the inequalities created by free markets, at least until a substantial middle class emerges, so democratization and marketization may pull in different directions for a time. In order to stave off internal hostility in such situations, States must ensure that domestic inequality is contained and that appropriate redistributive measures are in place, ${ }^{69}$ again indicating that the process should be managed and properly sequenced.

\section{Chilling Impact}

A systemic issue which arises with regard to the interaction of human rights law and trade law is the extent to which the latter rules may have a "chilling effect" on the will of States to implement their human rights obligations. In respect to the right to health, for example, a

\footnotetext{
64 See Griswold, Trading Tyranny for Freedom: How Open Markets till the soil for Democracy, Cato Institute (6 January 2004), available at: http://www.cato.org/publications/trade-policy-analysis/trading-tyranny-freedomhow-open-markets-till-soil-democracy (accessed 16 March 2015).

65 Gervais, TRIPS 3.0: Policy calibration and innovation displacement, in: Thomas/Trachtmann (eds.), Developing Countries in the WTO legal system, 2009, p. 393.

66 See statistics cited in Joseph, Blame it on the WTO: A Human Rights Critique, 2011, pp. 166-167.

67 Pogge, Growth and Inequality: Understanding Recent Trends and Political Choices, Dissent 6 (Winter 2008).

68 See generally Chua, The Paradox of Free Market Democracy: Rethinking Development Policy', Harvard International Law Journal 41 (2000), p. 287.

69 Wolf, Why Globalisation Works, 2005, p. 29.
} 
State may wish to ban or prevent the importation of toxic products which harm consumer health.

WTO obligations have a very broad scope. Free trade rules have traditionally targeted protectionism, that is measures that discriminate in favour of local products against foreign products. Other WTO obligations suggest a more broad-based "freedom to trade" divorced from notions of discrimination, which imposes greater restrictions on the regulatory capacities of a State. ${ }^{70}$ This shrinkage of policy space could limit the ability of a State to regulate in respect to essential services and utilities, thereby failing to meet such core human rights obligations as the provision of safe drinking water and sanitation. ${ }^{71}$

WTO agreements do contain exceptions which might facilitate reconciliation with human rights law in the case of conflict. In particular, Article XX of the GATT and the similar Article XIV of the General Agreement on Trade in Services allow a State to adopt measures necessary to protect morals and public health. For example, the recent Seals dispute confirmed that measures to protect "public morals" (under Article XX(a) of the GATT) can include measures to promote animal welfare so as to satisfy the moral tastes of the local population. ${ }^{72}$ One could extrapolate that certain human rights measures, such as a ban on the products built by child labourers, could be enacted in a similar manner.

However, the exceptions to WTO regimes have been interpreted with very high degrees of scrutiny, to the point that a State may still hesitate to rely on them in regulating imports to support human rights. Indeed, social measures have rarely survived WTO challenges intact (though there have not been many cases). Even the Seals legislation has to be amended in order to be fully WTO compliant.

\section{Possible Direct Conflicts - TRIPS and Human Rights Law}

Direct conflicts between a State's obligations under international human rights law and WTO law may most obviously arise under the Agreement on Trade Related Aspects of Intellectual Property Rights ("TRIPS"). Under TRIPS, WTO Members are required to protect intellectual property (“IP") rights, such as copyright, patents and trademarks. The Least Developed Countries do not have to fully comply with TRIPS until 2021.

IP rights are justified by the rewards they deliver to creators, innovators, inventors and authors, and the consequent incentives they deliver to research and development. TRIPS mandates the erection of barriers to trade in the form of temporary monopoly rights, so its inclusion within the WTO is anomalous. Indeed, the inclusion of TRIPS within the WTO

\footnotetext{
70 Driesen, What is Free Trade? The Real Issue Lurking behind the Trade and Environment Debate, Virginia Journal of International Law 41 (2001), p. 279.

71 See Lang, The GATS and Regulatory Autonomy: a Case Study of Social Regulation of the Water Industry, Journal of International Economic Law 7 (2001), p. 801.

72 Appellate Body Report, European Communities - Measures Prohibiting the Importation and Marketing of Seal Products, WT/DS400/AB/R and WT/DS401/AB/R (May 22, 2014). See Howse/Langille/Sykes, Sealing the Deal: the WTO’s Appellate Body Report in EC-Seal Products, ASIL Insights (4 June 2014), available at: http://www.asil.org/insights/volume/18/issue/12/sealing-deal-wto $\%$ E2\%80\%99s-appellate-body-report-ec\%E2\%80\%93-seal-products (accessed 15 March 2015).
} 
exposes neoliberals to charges of hypocrisy, as TRIPS mandates considerable State intervention in the economy in one particular area, which happens to generate huge benefits for corporate interests.

However, IP protection is said to indirectly boost trade because foreign investment and technology transfer is promoted when investors are confident that their valuable IP rights will be respected in the host State. ${ }^{73}$ IP protection should also promote local innovation within a State by protecting investments in research and development from pirates and copycats. ${ }^{74}$

Are IP rights human rights? Article 15(1)(c) of the ICESCR recognizes the right of everyone "to benefit from the protection of the moral and material interests resulting from any scientific, literary or artistic production of which he is the author". The UN Committee on Economic Social and Cultural Rights has distinguished Article 15(1)(c) rights from IP rights. The right in Article 15(1)(c) protects "the personal link between authors and their creations and between peoples, communities, or other groups and their collective cultural heritage, as well as their material interests which are necessary to enable authors to enjoy an adequate standard of living". In contrast, IP rights "primarily protect business and corporate interests and investments". ${ }^{75}$ In that respect, the Committee underlined that Article 15(1)(c) rights vest only in human beings, rather than corporations. ${ }^{76}$ Furthermore, the Committee anticipates that a variety of regimes, including but not limited to IP-like regimes, could suffice to satisfy Article 15(1)(c) ${ }^{77}$ This is quite different to the "one size fits all" regime in TRIPS.

The most prominent human rights concern regarding TRIPS has been its alleged negative impact access to medicines for poor people, because compulsory patent protection for pharmaceutical products raises prices beyond their reach. In his 2009 Report to the UN Human Rights Council, the Special Rapporteur on the Right to Health, Anand Grover, wrote extensively on this issue. Grover's report implies that TRIPS obligations do not conflict with the right of access to medicines, though he still found that TRIPS has "had an adverse impact

\footnotetext{
${ }^{73}$ See Singham, Competition Policy and the Stimulation of Innovation: TRIPS and the Interface Between Competition and Patent Protection in the Pharmaceutical Industry, Brooklyn Journal of International Law 26 (2000), p. 363 (375-385).

${ }^{74}$ However, it has been argued that this rationale for TRIPS effectively put "the policy cart before the empirical horse": Gervais, TRIPS 3.0: Policy calibration and innovation displacement, in: Thomas/Trachtmann (eds.), Developing Countries in the WTO legal system, 2009, p. 370.

75 Committee on Economic, Social and Cultural Rights, General Comment No. 17: The right of everyone to benefit from the protection of the moral and material interests resulting from any scientific, literary or artistic production of which he or she is the author (art. 15, para. 1(c)), UN doc. E/C.12/GC/17 (12 January 2006), para 2.

76 Committee on Economic, Social and Cultural Rights, General Comment No. 17: The right of everyone to benefit from the protection of the moral and material interests resulting from any scientific, literary or artistic production of which he or she is the author (art. 15, para. 1(c)), UN doc. E/C.12/GC/17 (12 January 2006), para 7.

77 Committee on Economic, Social and Cultural Rights, General Comment No. 17: The right of everyone to benefit from the protection of the moral and material interests resulting from any scientific, literary or artistic production of which he or she is the author (art. 15, para. 1(c)), UN doc. E/C.12/GC/17 (12 January 2006), paras 2, 16 and 47
} 
on prices and availability of medicines". ${ }^{78}$ He urged developing States to utilise all available TRIPS flexibilities, as needed, in order to ensure access to medicines domestically. Their common failure to do so, which is often prompted by economic and diplomatic pressure from richer States and international financial institutions, amounted in Grover's view to a violation of the right to health in Article 12 of the ICESCR.

A burgeoning debate now relates to the compatibility between global copyright regimes and human rights law. For example, copyright laws obstruct access to educational materials by raising their price. ${ }^{79}$ Obstacles to basic education are counterproductive to a State's aspirations for economic, institutional and social development.

In late 2014, the UN Special Rapporteur on Cultural Rights, Farida Shaheed, issued a report on copyright and the right to science and culture in Article 15 of the ICESCR. ${ }^{80}$ While the report is largely designed to help ensure the injection of human rights concerns into ongoing discussions of global copyright regimes, it also draws attention to possible ways in which modern copyright regimes might undermine human rights. She suggests that overly strong copyright regimes can unduly limit "cultural freedom and participation" (para 27), and punitive approaches to the punishment of digital piracy (eg denial of Internet access) can breach "the right to freedom of expression and the right to science and culture" (para 51). Rather, copyright regimes should "ensure a vibrant public domain of shared cultural heritage, from which all creators are free to draw" (para 50). She also notes how copyright regimes have failed to protect and respond to "the unique concerns of Indigenous peoples" (para 56).

The TRIPS regime provides weaker IP protection, and therefore allows for more policy space, than the "TRIPS-plus" regimes which are commonly adopted within regional or bilateral trade treaties. If a State bound by TRIPS plus commitments is a Member of the WTO, it may have to guarantee equivalent rights to traders from all other States in the WTO, due the Most Favoured Nation principle. ${ }^{81}$

\section{Investment Law and Human Rights}

Bilateral investment treaties ("BITs") emerged in the post-war decolonisation period as a means of protecting foreign investors, largely from developed States, from expropriation by developing States. ${ }^{82}$ By the 1980s and 1990s, BITs proliferated, even between developing

\footnotetext{
${ }^{78}$ Human Rights Council, Report of the Special Rapporteur on the right of everyone to the enjoyment of the highest attainable standard of physical and mental health, Anand Grover, UN doc. A/HRC/11/12 (31 March 2009), para 94.

79 See, generally, Chon, Intellectual Property from Below: Copyright and Capability for Education, U.C. Davis L. Rev. 40 (2006-2007), p. 803; 3D, The Philippines: Impact of copyright rules on access to education (June 2009), available at: http://www.crin.org/docs/3DCRC_PhilippinesJun09.pdf (accessed 15 March 2015).

${ }^{80}$ UN doc. A/HRC/28/57 (24 December 2014).

81 Abbott/Reichmann, The Doha Round's Public Health Legacy: Strategies for the Production and Diffusion of Patented Medicines under the Amended TRIPS Provisions, Journal of International Economic Law 10 (2007), p. 921 (963-964)

82 A good history of BITs is found in Vandevelde, The Political Economy of a Bilateral Investment Treaty, American Journal of International Law 92 (1998), p. 621.
} 
States, as they came to be seen as a norm in governing international investment. ${ }^{83}$ However, since the turn of the century, there has been a downturn in the number of new investment treaties.

BITs are said to promote foreign investment in a country ${ }^{84}$ which provides jobs, tax revenue, the transfer of technology and skills, foreign currency reserves, local business for subcontractors and local competition to the benefit of consumers. Increases in wealth provide further resources which should improve the capacity of States to progressively implement their ESC rights obligations. Furthermore, foreign investors may influence States positively by demanding adherence to the rule of law, as arbitrary decision-making intolerably threatens their investments. ${ }^{85}$

BITs act as "bills of rights" for a State's investors when they operate in the territory of the other party. Examples of substantive rights in BITs include guarantees against direct and indirect expropriation, non-discrimination in comparison with local investors, and fair and equitable treatment. The web of investment treaties in existence do not follow a particular model, and therefore contain materially different substantive obligations. ${ }^{86}$

These substantive rights are often supplemented by significant procedural rights. Numerous BITs allow investors to bring their claims against governments directly to international arbitral tribunals, bypassing local judicial systems. These provisions reflect the post-war lack of trust in post-colonial judicial systems, which may still be warranted in the many States where the judiciary lacks real independence.

Arbitral tribunals are typically made up of three arbitrators with commercial expertise. Awards can entail the payment of considerable compensation and other ameliorating measures to an investor, often in the hundreds of millions of dollars. ${ }^{87}$ States are legally obliged to abide by arbitral awards. Failure to comply will likely attract economic and political pressure from the bilateral party to the BIT, and will jeopardise a State's reputation with regard to foreign investors generally. Therefore, as with trade regimes, enforcement under some investment treaties is strong as significant economic consequences can flow from breach.

Rights under BITs are very broad and vague, and are often claimed by investors to protect them from regulatory changes which diminish likely future profits. This is problematic as many regulatory changes, which may diminish business profits, are supportive of the

\footnotetext{
83 See Jandhyala/Henisz/Mansfield, Three Waves of BITs: the Global Diffusion of Foreign Investment Policy, Journal of Conflict Resolution 55 (2011), p. 1047.

${ }^{84}$ However, the common assumption that BITs encourage foreign investment in a State may be challengeable: see Hallward-Driemeyer, Do Bilateral Investment Treaties Attract FDI? Only a bit... and they could bite, World Bank Policy Research Paper No. 3121, 2003.

85 See, eg, World Bank, World Development Report 2002: Building Institutions for Markets, 2002, available at: http://www.worldbank.org/wdr/2001/fulltext/fulltext2002.htm (accessed 20 September 2010).

86 Karamanian, Human Rights Dimensions of Investment Law, in: de Wet/Widmar (eds.), Hierarchy in International Law: The Place of Human Rights, 2012, p. 243.

87 Kriebaum, Is the European Court of Human Rights an Alternative to Investor-State Arbitration?, in: Dupuy/Francioni/Petersmann (eds.), Human Rights in International Investment Law and Arbitration, 2009, p. 244.
} 
fulfilment of human rights, such as environmental or health regulations, and price caps or cross-subsidies to facilitate the availability of essential utilities for the poor. Furthermore, many BITs do not explicitly allow exceptions to permit regulations in areas of public interest.

This "chilling" problem is exacerbated by unpredictability within the investment arbitration regime. There is no overarching appellate system in the world of international investment arbitration. ${ }^{88}$ This circumstance is problematic as decisions, for example on the meaning of "expropriation" or on the existence and scope of public interest regulation exceptions, are inconsistent. ${ }^{89}$ Furthermore, the arbitral system suffers from a lack of transparency: proceedings are often held in secret. ${ }^{90}$ As the pool of arbitrators is quite small, the potential for conflicts of interest arises as a person may be involved in one case as counsel, and in another as an arbitrator over similar legal issues. ${ }^{91}$

\section{Investment cases}

Conflicts between a State's obligations under international human rights law and international investment law can arise when a claim by a foreign investor against a government prejudices the human rights of third parties.

For example, in Glamis Gold v United States, a Canadian company claimed that Californian mining regulations, which diminished the value of its mining investment, breached the US's obligations to Canadian investors under the North American Free Trade Agreement. Those same regulations were argued to preserve the human rights of third parties, such as their minority rights under Article 27 of the ICCPR, to which the US is a party. The Quechuan Indian nation filed an amicus brief against the Glamis claim. ${ }^{92}$ In the result, the arbitral tribunal found that it did not have to make any ruling on the human rights issues, as Glamis's claim failed for other reasons. ${ }^{93}$

In Foresti et al $v$ South Africa, Italian mining companies challenged the South African Black Economic Empowerment Laws, which had been adopted to redress historic economic disadvantage for non-whites. The mining companies argued that the empowerment laws rendered their mining rights less valuable and amounted to expropriation as well as breaches

\footnotetext{
88 Arbitral awards may be reviewed on narrow grounds by courts in proceedings regarding enforcement of the award. See Fry, International Human Rights Law in Investment Arbitration: Evidence of International Law's Unity, Duke Journal of International and Comparative Law 18 (2007-2008), p. 77 (118-119).

89 Fry, International Human Rights Law in Investment Arbitration: Evidence of International Law's Unity, Duke Journal of International and Comparative Law 18 (2007-2008), p. 77 (83-84).

90 Fry, International Human Rights Law in Investment Arbitration: Evidence of International Law's Unity, Duke Journal of International and Comparative Law 18 (2007-2008), p. 77 (115-117).

91 Goldhaber, The Rise of Arbitral Power over Domestic Courts, Stanford Journal of Complex Litigation 1 (2013), p. 373 (407-408).

92 See Application for Leave to File a Non-party Submission and Submission of the Quechan Indian Nation, available at: http://www.state.gov/documents/organization/52531.pdf (accessed 15 March 2015) p. 8. Amicus briefs may be submitted to tribunals though the tribunals do not have to accept them, or take them into consideration in making decisions.

${ }^{93}$ See Tribunal Award, available at: http://www.state.gov/documents/organization/125798.pdf (accessed 15 May 2015) p. 22.
} 
of requirements of 'fair and equitable treatment'. ${ }^{94}$ Aguas del Tunari v Bolivia concerned a claim by a consortium regarding the cancellation of a contract to run water utilities in the Bolivian city of Cochabamba. Critics claimed that access to water had been limited by the consortium's high prices, which led to civil unrest. The cancellation arguably enhanced the right of access to water in Cochabamba. ${ }^{95}$

Foresti and Aguas del Tunari were discontinued after significant civil society outrage. So perhaps the perceived bark of investment law is worse than its actual bite. However, the doctrine of precedent does not operate within international investment law, and similarsounding obligations under different BITS may be relevantly different. Furthermore, the costs involved for a State in defending arbitral challenges are considerable. South Africa's aborted defence in the Foresti proceedings cost $€ 5$ million of which the claimants only paid $€ 400,000 .{ }^{96}$ Therefore, the chilling impact of investment law upon a State's willingness to implement its human rights obligations remains apparent.

\section{Chevron-Ecuador}

A new possible threat posed by investment arbitration to human rights norms emerged in a dispute between Chevron and Ecuador. The case concerns long-running litigation regarding legal responsibility for grave environmental harm caused to homelands of the Lago Agrio Indigenous peoples by oilspills and dumped waste. Having won a $\$ 19$ billion judgment in an Ecuadorian court, the plaintiffs face the possibility of that judgment being effectively overruled by an arbitral panel.

The facts of this dispute are contested and very complex. ${ }^{97}$ The following is a short summary. From 1967 to 1990, Texaco was involved in oil exploration in the Lago Agrio oilfields in the Ecuadorian Amazon as part of a consortium. Terrible environmental practices prevailed, and probably continued after Texaco's exit in 1990. Litigation against Texaco in respect of grave environmental damage commenced in the US in 1993 by groups of Indigenous plaintiffs from the Lago Agrio. In 2002, US courts declined jurisdiction over the matter, deeming Ecuador to be the more appropriate forum, in line with Texaco's constant arguments. Litigation against Chevron, which had merged with Texaco in 2001, commenced in Ecuador in 2003. In 2011, Judge Zambrano ruled in favour of the plaintiffs, awarding them \$US19 billion, which was confirmed on appeal. Chevron does not have significant assets in Ecuador, so the plaintiffs are seeking enforcement of the judgment in other jurisdictions.

In 2009, Chevron commenced action against Ecuador in the Permanent Court of Arbitration ("PCA"), claiming various breaches of a BIT between the US and Ecuador, to

\footnotetext{
94 Award and decision to discontinue available at: http://icsid.worldbank.org/ICSID/FrontServlet?requestType=CasesRH\&actionVal=showDoc\&docId=DC1651 En\&caseId $=$ C90 (accessed 15 March 2015).

${ }^{95}$ See Bechtel Bows to Bolivia, Multinational Monitor 27 (January-February 2006) 1, p. 4.

96 Peterson, South Africa Mining Arbitration ends with a Whimper, as terms of Discontinuance are set out in the award, Investment Arbitrator Reporter (5 August 2010), available at: http://www.iareporter.com/articles/20100818 6 (accessed 15 March 2015).

97 See, eg, Joseph, Protracted Lawfare: the tale of Chevron Texaco in the Amazon, Journal of Human Rights and the Environment 3 (2012), pp. 70-91.
} 
prevent the judgment from being handed down. It claims that the proceedings were tainted by fraud by the court as well as the plaintiffs' legal team. Since Zambrano's judgment was issued in February 2011, it now seeks an order for Ecuador to do all it can to prevent execution or enforcement of the judgment, or to indemnify Chevron for any damage caused by such enforcement. The PCA has issued several interim orders to Ecuador, seeking to prevent enforcement of the judgment. ${ }^{98}$ In late 2013, it also handed down its decision on one aspect of the merits of the case, which favoured Chevron. ${ }^{99}$ The merits phase is expected to conclude in 2015.

Chevron is essentially attempting to thwart, via the route of investment arbitration, a judgment obtained in Ecuador by the Lago Agrio plaintiffs who are not party to, and are excluded from, the investment arbitration proceedings. That judgment was obtained after 16 years of litigation in two countries. Amici briefs submitted on behalf of the Lago Agrio plaintiffs were summarily rejected by the tribunal, even though their interests are undoubtedly at stake in the arbitration.

Chevron's complaints before the PCA focus on alleged corruption within the Ecuadorian legal system, despite the adequacy of that legal system being asserted vigorously by the predecessor company, Texaco, in order to remove the litigation from US courts against the wishes of the plaintiffs. Ironically, the arbitral panel is judging the adequacy of Ecuadorian due process whilst failing to satisfy standard due process requirements itself: for example its proceedings are held in secret and no appeal will be available. ${ }^{100}$

This author is not in a position to know if Chevron's claims of fraud are true. Yet the company does not seem to have clean hands. Chevron was quite happy with the Ecuadorian legal system, as Texaco had been, prior to the ascent of the populist government of Rafael Correa in 2007. The legal system was probably no less corrupt beforehand, but prior to Correa it favoured Texaco and later Chevron. ${ }^{101}$ Wikileaks cables indicate that Chevron had lobbied the US government to punish Ecuador with trade sanctions, and had also itself sought to influence the Ecuadorian government in its favour in 2008. ${ }^{102}$

The plaintiffs' attempts to seek a remedy in the US failed, leaving them with no option but to seek a remedy in Ecuador. It may be that, as the plaintiffs had argued in the US, a fair hearing on such a complex matter with political and economic repercussions was simply not possible in Ecuador's underdeveloped legal system. Perhaps, as argued by Chevron, that

\footnotetext{
98 See, eg, PCA Case No. 2009-23, Chevron and Texaco v. Ecuador, Fourth Interim Award on Interim Measures (7 February 2013).

99 PCA Case No 2009-23, Chevron and Texaco v Ecuador, First Partial Award on Track 1 (17 September 2013). This decision focused on the interpretation of remediation agreements concluded between Texaco and Ecuador in 1995 and 1998.

100 Goldhaber, The Rise of Arbitral Power over Domestic Courts, Stanford Journal of Complex Litigation 1 (2013), p. 373 (406-410).

101 Joseph, Protracted Lawfare: the tale of Chevron Texaco in the Amazon, Journal of Human Rights and the Environment 3 (2012), p. 70 (87).

102 Joseph, Protracted Lawfare: the tale of Chevron Texaco in the Amazon, Journal of Human Rights and the Environment 3 (2012), p. 70 (85).
} 
unfairness fell upon it in Zambrano's judgment. But Chevron, unlike the plaintiffs, now has the option of seeking justice before an arbitral panel.

What could the plaintiffs have done if they had felt similarly aggrieved by the Zambano judgment? As it happens, the Lago Agrio plaintiffs filed a petition with the Inter American Commission on Human Rights in 2011, seeking interim relief against Ecuador to prevent it from complying with the PCA's interim awards. ${ }^{103}$ That petition has been discontinued. The fact of the petition confirms that the IACHR provides the plaintiffs with an international avenue of relief, a rival to the PCA route available to Chevron. A clearer potential manifestation of international "fragmentation" between different areas of international law may be hard to find. There was, and even remains, the possibility of two international forums, the PCA and the IACHR, ordering Ecuador to take two diametrically courses of action. In such a contest, as noted above, Ecuador's ultimate course may be influenced by the relative strengths of the relevant enforcement regimes.

However, the PCA's insertion into the drama has been unsuccessful. Ecuador is not complying with its interim orders, which may be why the IACHR petition was discontinued. Furthermore, a US court has declined to enforce the PCA's interim orders. ${ }^{104}$ The current Ecuadorian government seems unlikely to comply with any final merits decision in favour of Chevron. Indeed, in presuming to effectively overrule Ecuadorian courts on the Chevron matter, the arbitral tribunal may have acted without prudence and beyond what States are actually prepared to put up with from secret three-person commercial tribunals. ${ }^{105}$

Meanwhile, the litigation continues outside the PCA. A US court has refused to enforce the Ecuadorian judgment (for reasons unrelated to the PCA), ${ }^{106}$ but the plaintiffs are seeking enforcement in other jurisdictions, including Canada, Brazil and Argentina. The ongoing saga demonstrates how hard it is to hold a multinational corporation to account for harm caused in a developing State. Victims in such situations may be deprived of any practical right to a remedy. While the prolonged drama rolls on, the Lago Agrio oilfields remain polluted, with devastating impacts on the local environment, culture and health.

\section{Conclusion}

There are certainly synergies between the relevant economic law regimes and economic social and cultural rights, as well as civil and political rights. Certainly, all three systems are concerned with the promotion of human agency and human flourishing.

\footnotetext{
${ }^{103}$ Low, The Chevron-Ecuador Dispute: A Paradigm of Complexity, American Society of International Law Proceedings (28-31 March 2012), p. 419 (421).

104 Chevron v. Naranjo, 667 F. 3d 232 (2 ${ }^{\text {nd }}$ Cirt, 2012).

105 See generally, Goldhaber, The Rise of Arbitral Power over Domestic Courts, Stanford Journal of Complex Litigation 1 (2013), pp. 373-416.

${ }^{106}$ Chevron v. Donziger, US District Court, Southern District of New York (4 March 2014), available at: http://www.theamazonpost.com/wp-content/uploads/Chevron-Ecuador-Opinion-3.4.14.pdf (accessed 16 March 2015).
} 
However, one must not be complacent in presuming the compatibility of the international economic legal regimes with human rights law. Those regimes essentially promote the rights of a privileged few, namely foreign traders and investors, ${ }^{107}$ which may lead to the inevitable prioritisation of their rights when they clash with or otherwise detract from the human rights of others. Such a prioritisation is unfortunate if it adds to the already great capacity for powerful entities to override the interests of the powerless and marginalised.

107 See, eg, Alvarez, Critical Theory and the North American Free Trade Agreement's Chapter Eleven, University of Miami Inter-American Law Review 28 (1997), p. 303 (307-9). 